\title{
Surface Currents off Oregon as Determined from Drift Bottle Returns
}

\author{
Bruce Wyatt, Wayne V. Burt and June G. Patrullo \\ Dept. of Oceanography, Oregon State University, Corvallis 97331
}

(Manuscript received 24 December 1971, in revised form 15 March 1972)

\begin{abstract}
It is generally known that surface currents off Oregon flow equatorward in summer when winds are from the northwest and poleward in the winter when winds are from the south. A detailed pattern of surface currents has been derived from drift bottle returns and releases observed during a 10-year study from 1961-71. A total of 21,285 drift bottles were released within $165 \mathrm{n} \mathrm{mi}$ of the Oregon coast, of which 2937 bottles were eventually recovered. The annual cycle of surface currents indicated from these returns was as follows:

Northward-October through February

Southward-May through August

Variable-March, April and September

The Davidson current or (northward) winter current was considered to be any northward prevalence of surface flow. The Davidson current commonly reached 48-50N. Every year of the study, some surface flow off Oregon reached as far north as southeast Alaska to about 55N. Although drift bottle observations often indicate northward surface flow all the way to at least the edge of the study area, $165 \mathrm{mi}$ offshore, it is believed the main flow of the Davidson current occurs within $100 \mathrm{mi}$ of the coast of Oregon and Washington. Maximum speeds between 0.5 and $2 \mathrm{kt}$ occurred within $20 \mathrm{mi}$ of the coast during the month of November. Southward surface currents near $0.30 \mathrm{kt}$ were occasionally measured in summer, and they appeared to be consistent for a distance up to $200 \mathrm{mi}$ along the coast. Mean surface currents in both summer and winter were $0.2 \mathrm{kt}$ ( $150 \mathrm{n} \mathrm{mi} \mathrm{per} \mathrm{month).} \mathrm{Unseasonal} \mathrm{winds} \mathrm{during} \mathrm{both} \mathrm{winter} \mathrm{and} \mathrm{summer}$ resulted in anomalous currents. The major direction changes of currents from northward to southward occurred in March and April. The shift in currents back to northward occurred in September, a time when onshore surface flow was also prominent.
\end{abstract}

\section{Introduction}

Knowledge of surface currents is important in understanding the distribution of organisms such as salmon and tuna, as well as plankton along the coast. It is certainly important in predicting the dispersal of surface pollutants such as an oil spill, etc. It is not inconceivable that an oil spill off southern Oregon might be spread by currents along the entire coastline in a little more than a week. Most users of coastal waters from sports fishermen to ship operators need to know how surface currents can be expected to flow at any given time of the year.

The west wind drift current off the Pacific Northwest splits to form two eastern boundary currents off the Oregon and Washington coasts. The California current flows equatorward and the Alaska current periodically flows poleward. A third current often referred to as the Davidson current flows poleward at the surface on the inshore side of the California current to at least $48 \mathrm{~N}$. Burt and Wyatt (1964) and Schwartzlose (1964) used drift bottles to define the Davidson current in winter. Current meter measurements within $30 \mathrm{mi}$ of the Oregon coast were completed by Collins (1968) and Mooers (1970), who found poleward flow at depths of 20 and $120 \mathrm{~m}$ in fall and winter and equatorward flow near the surface in summer. Stevenson et al. (1969), using parachute drogues at $10 \mathrm{~m}$ depth, found currents primarily southward particularly off Newport in summer.

The objective of this study was to describe the seasonal and spatial character of the surface currents off the Oregon coast. Drift bottle releases and recoveries from the coast line to $165 \mathrm{mi}$ offshore over a 10-year period from 1961-71 were the main data sources. Results include estimates of speed and direction of currents throughout the year.

\section{Drift bottle releases}

The Oregon coast is a good region for drift bottle studies. Measurements of currents over a large area is possible at low cost. Sandy beaches which provide drift bottle return sites are numerous along the entire coastline. These beaches are well patrolled by beachcombers, and reports of drift bottles are numerous.

Drift bottles were released all along the Oregon coast on 80 of 120 months from 1961 to 1971 (Table 1). Release points were $5,15,25,35,45,65,105,125,145$ and $165 \mathrm{mi}$ west of the coast line from Newport, Ore. (Table 2). Releases were made intermittently at similar 
TABLE 1. Return rates (percent) for drift bottle releases off the Oregon coast 1961-71. General trajectories for returns from each cruise are also presented.

\begin{tabular}{|c|c|c|c|c|c|c|c|c|c|c|c|c|c|}
\hline \multirow{3}{*}{$\begin{array}{l}\text { Month } \\
\text { of re- } \\
\text { lease }\end{array}$} & \multirow{2}{*}{\multicolumn{10}{|c|}{ Years when releases were made }} & \multirow{3}{*}{$\begin{array}{l}\text { General } \\
\text { direction } \\
\text { of returns }\end{array}$} & \multicolumn{2}{|c|}{ Totals } \\
\hline & & & & & & & & & & & & $\begin{array}{c}\text { Range in } \\
\text { return }\end{array}$ & $\begin{array}{c}\text { Total } \\
\text { number of } \\
\text { releases for }\end{array}$ \\
\hline & 1961 & 1962 & 1963 & 1964 & 1965 & 1966 & 1967 & 1968 & 1969 & 1970 & & rate & each month \\
\hline Jan & $7(\mathrm{~N})$ & $23(N)$ & $35(\mathrm{~N})$ & & & $13(N)$ & $24(\mathrm{~N})$ & $27(N)$ & $19(N)$ & $14(\mathrm{~N})$ & $\mathrm{N}$ & $7-35$ & 8 \\
\hline Feb & & $30(N-S)$ & $29(\mathrm{~N})$ & $0(\mathrm{~S})$ & $4(N-S)$ & & $27(\mathrm{~N})$ & $15(\mathrm{~N}-\mathrm{S})$ & $11(N)$ & $15(\mathrm{~N})$ & $\mathrm{N}$ & $11-30$ & 8 \\
\hline Mar & $30(\mathrm{~S})$ & $0(\mathrm{~S})$ & $29(\mathrm{~N})$ & & $14(\mathrm{~N})$ & $4(S)$ & & $18(\mathrm{~N}-\mathrm{S})$ & & & $\mathrm{N}-\mathrm{S}$ & $0-30$ & 6 \\
\hline Apr & $47(\mathrm{~N}-\mathrm{S})$ & $26(\mathrm{~N}-\mathrm{S})$ & & $1(S)$ & $36(\mathrm{~N})$ & $0(\delta)$ & $2(S)$ & $1(\mathrm{~S})$ & & & $\mathrm{N}-\mathrm{S}$ & 047 & 7 \\
\hline May & $3(\mathrm{~S})$ & & $0(S)$ & & & & $0(\mathrm{~S})$ & $13(S)$ & $19(\dot{S})$ & $16(S)$ & $\mathbf{S}$ & $0-19$ & 6 \\
\hline Jun & $1(\$)$ & $2(S)$ & & & & & $7(\mathrm{~S})$ & $18(S)$ & $8(S)$ & $2(S)$ & $\mathbf{S}$ & $1-18$ & 6 \\
\hline Jul & $8(S)$ & $14(S)$ & $7(\$)$ & $4(S)$ & $3(S)$ & $2(S)$ & $8(S)$ & $10(\mathrm{~S})$ & & & $\mathrm{S}$ & $2-14$ & 8 \\
\hline Aug & $4(S)$ & $3(\mathrm{~S})$ & & & & & $35(\mathrm{~N}-\mathrm{S})$ & $15(N-S)$ & $11(\mathrm{~N}-\mathrm{S})$ & & $\mathrm{S}$ & $3-35$ & 5 \\
\hline Sep & & $24(\mathrm{~N}-\mathrm{S})$ & $31(N)$ & & & $22(\mathrm{~N}-\mathrm{S})$ & & $30(N-S)$ & $21(N-S)$ & & $\mathrm{N}-\mathrm{S}$ & $21-30$ & 5 \\
\hline Oct & $18(\mathrm{~N})$ & $8(N)$ & & & & & $36(N)$ & $16(N)$ & $12(\mathrm{~N})$ & & $\mathbf{N}$ & $8-36$ & 5 \\
\hline Nov & & & $11(N)$ & $20(N)$ & $25(\mathrm{~N})$ & $15(\mathrm{~N})$ & $35(N)$ & $26(N)$ & $6(N)$ & $34(\mathrm{~N}-\mathrm{S})$ & $\mathrm{N}$ & $6-35$ & 8 \\
\hline Dec & $46(N)$ & $11(\mathrm{~N}-\mathrm{S})$ & & $10(\mathrm{~N})$ & $27(\mathrm{~N})$ & $10(N)$ & & $5(\mathrm{~N})$ & & $28(N)$ & $\mathbf{N}$ & $5-46$ & 7 \\
\hline
\end{tabular}

Explanation of symbols

Numbers indicate return rates in percent of bottles released.

(N)-Bottles picked up north of release points.

(S) - Bottles picked up south of release points.

(N-S)-Bottles picked up north and south of release points.

intervals west of Brookings (42N), Coos Bay (43N), Depoe Bay (45N) and Astoria (46N), Ore., as well as Newport (Table 1). On the Newport line $\left(44^{\circ} 40^{\prime} \mathrm{N}\right)$, releases over the 10 -year study were well distributed through the various months, and there was no obvious bias favoring a particular time period or weather period (Table 1). A total of 21,285 bottles were released and 2937 bottles were eventually recovered at various locations along the coast west of the United States and Canada. Releases exclusively on the Newport line numbered 9456 , of which 1375 , or $14.5 \%$, were eventually returned. Over three-fourths of all returns were picked up north of release points. Most bottles traveled less than $300 \mathrm{mi}$. Drift bottle return rates were higher from releases off Oregon than for other areas off the West Coast. Schwartzlose (1964) reported only a $2.5 \%$ return rate for 8966 releases off northern California. Dodimead and Hollister (1962) had somewhat better success working about $1000 \mathrm{mi}$ off Oregon and Washington in the west wind drift. They released 14,420 bottles and reported a return rate of $6.1 \%$. The higher return rate for releases off Oregon may in part be attributed to the rate of bottle releases within $25 \mathrm{mi}$ of the coast. About one-fourth of all bottles were released in this nearshore area and the return rate over the 10-year study was as high as $33 \%$ for the station $5 \mathrm{mi}$ offshore. There was a small bias toward drift bottle recoveries on weekends and a significant

TABLE 2. Drift bottle return rates (percent) for stations west of Newport, Oreg., 1961-71. Return rates consist of all returns over the 10-year study divided by all releases. Returns were classified as either north or south. The percent of north recoveries (bottles traveling toward the north) is given in the table. The percent of recoveries made south of release points may be derived by subtracting the number given in the table from $100 \%$.

\begin{tabular}{|c|c|c|c|c|c|c|c|c|c|c|c|c|c|c|}
\hline \multirow[t]{2}{*}{$\begin{array}{l}\text { Month of } \\
\text { release }\end{array}$} & \multicolumn{12}{|c|}{$\begin{array}{c}\text { Release points } \\
\text { (n mi west of Newport) }\end{array}$} & \multirow{2}{*}{$\begin{array}{l}\text { Percent } \\
\text { return } \\
\text { all } \\
\text { stations }\end{array}$} & \multirow{2}{*}{$\begin{array}{c}\text { Percent } \\
\mathrm{N} \\
\text { all } \\
\text { station }\end{array}$} \\
\hline & 3 & 5 & 15 & 25 & 35 & 45 & 65 & 85 & 105 & 125 & 145 & 165 & & \\
\hline Jan & $7(100)^{*}$ & $37(88)$ & $31(94)$ & $24(92)$ & $12(80)$ & $19(95)$ & $25(100)$ & $7(60)$ & $3(100)$ & $4(100)$ & $4(100)$ & $11(92)$ & 17 & (91) \\
\hline Feb & $21(100)$ & $38(38)$ & $19(72)$ & $19(78)$ & $27(85)$ & $12(58)$ & $16(85)$ & $19(89)$ & $20(88)$ & $9(55)$ & $5(75)$ & $8(88)$ & 18 & (72) \\
\hline Mar & & $22(75)$ & $17(83)$ & $16(86)$ & $6(100)$ & $28(53)$ & $21(100)$ & $62(87)$ & & & & & 18 & (77) \\
\hline Apr & & $11(50)$ & $14(20)$ & $19(75)$ & $12(20)$ & $8(17)$ & & & & & & & 6 & (45) \\
\hline May & $54(85)$ & $40(84)$ & $18(33)$ & $11(18)$ & $5(0)$ & $2(0)$ & & & & & & & 9 & (38) \\
\hline Jun & & $21(48)$ & & $1(0)$ & & & & & & & & $1(100)$ & 3 & (48) \\
\hline Jul & & $22(50)$ & $14(17)$ & $5(40)$ & $10(40)$ & $1(100)$ & & & & & & $3(50)$ & 6 & (39) \\
\hline Aug & $71(47)$ & $45(52)$ & $23(57)$ & $14(50)$ & $18(55)$ & $2(0)$ & $14(80)$ & $3(0)$ & $6(0)$ & & $5(67)$ & $7(100)$ & 14 & (55) \\
\hline Sep & $75(0)$ & $65(59)$ & $40(79)$ & $38(70)$ & $20(83)$ & $12(86)$ & $57(91)$ & $23(57)$ & $15(67)$ & $18(73)$ & $33(45)$ & $7(50)$ & 30 & (77) \\
\hline Oct & $33(100)$ & $37(89)$ & $19(93)$ & $17(83)$ & $8(100)$ & $17(100)$ & $12(70)$ & $15(81)$ & $10(100)$ & $2(57)$ & $8(100)$ & $10(51)$ & 15 & (87) \\
\hline Nov & $33(0)$ & $33(88)$ & $23(93)$ & $17(90)$ & $17(91)$ & $22(9.3)$ & $11(100)$ & $20(89)$ & $17(81)$ & $30(72)$ & $15(91)$ & $12(84)$ & 21 & (86) \\
\hline Dec & & $18(91)$ & $17(100)$ & $23(65)$ & $13(100)$ & $21(100)$ & $15(100)$ & $10(80)$ & $6(100)$ & $10(80)$ & $10(100)$ & $8(100)$ & 15 & (91) \\
\hline Return & & & & & & & & & & & & & & \\
\hline $\begin{array}{l}\text { all months } \\
\text { North } \\
\text { returns }\end{array}$ & 34 & 33 & 19 & 17 & 13 & 13 & 14 & 12 & 8 & 7 & 7 & 6 & 14.54 & \\
\hline all months & (48) & (65) & (75) & (74) & (75) & (81) & (92) & (78) & $(86)$ & $(70)$ & (73) & $(81)$ & & (74) \\
\hline
\end{tabular}

* Number in parentheses indicates percent of bottles that were recovered north of release points. 
TABLE 3. Mean speeds and estimated direction of drift bottle returns for quarterly time intervals and for four different directions, 1961 -70. The data is for drift bottle releases and returns from stations off Newport, Ore.

\begin{tabular}{|c|c|c|c|c|}
\hline $\begin{array}{c}\text { Quarterly } \\
\text { time intervals }\end{array}$ & $\begin{array}{l}\text { General direction } \\
\text { of current }\end{array}$ & $\begin{array}{l}\text { Octal direction } \\
\text { from true north }\end{array}$ & $\begin{array}{l}\text { Percent of all returns } \\
\text { for listed quarter }\end{array}$ & $\begin{array}{l}\text { Mean speed of } \\
\text { returns for the } \\
\text { quarter and } \\
\text { direction listed } \\
(\mathrm{kt})\end{array}$ \\
\hline $\begin{array}{l}\text { Sep-Nov } \\
\text { Dec-Feb } \\
\text { Mar-May } \\
\text { Jun-Aug }\end{array}$ & $\begin{array}{l}\text { (North along } \\
\text { shore) }\end{array}$ & $\begin{array}{l}\text { NNE } \\
\text { NNE } \\
\text { NNE } \\
\text { NNE }\end{array}$ & $\begin{array}{l}71 \\
73 \\
42 \\
35\end{array}$ & $\begin{array}{l}0.19 \\
0.17 \\
0.22 \\
0.11\end{array}$ \\
\hline $\begin{array}{l}\text { Sep-Nov } \\
\text { Dec-Feb } \\
\text { Mar-May } \\
\text { Jun-Aug }\end{array}$ & $\begin{array}{l}\text { On shore } \\
\text { Along shore } \\
\text { (Components } \\
\text { about equal) }\end{array}$ & $\begin{array}{l}\text { ENE } \\
\text { ENE } \\
\text { ENE } \\
\text { ENE }\end{array}$ & $\begin{array}{l}14 \\
11 \\
12 \\
22\end{array}$ & $\begin{array}{l}0.09 \\
0.06 \\
0.07 \\
0.07\end{array}$ \\
\hline $\begin{array}{l}\text { Sep-Nov } \\
\text { Dec-Feb } \\
\text { Mar-May } \\
\text { Jun-Aug }\end{array}$ & $\begin{array}{l}\text { On shore } \\
\text { Along shore } \\
\text { (Components } \\
\quad \text { about equal) }\end{array}$ & $\begin{array}{l}\text { ESE } \\
\text { ESE } \\
\text { ESE } \\
\text { ESE }\end{array}$ & $\begin{array}{r}9 \\
7 \\
10 \\
13\end{array}$ & $\begin{array}{l}0.08 \\
0.06 \\
0.08 \\
0.07\end{array}$ \\
\hline $\begin{array}{l}\text { Sep-Nov } \\
\text { Dec-Feb } \\
\text { Mar-May } \\
\text { Jun-Aug }\end{array}$ & $\begin{array}{l}\text { (South along } \\
\text { shore) }\end{array}$ & $\begin{array}{l}\text { SSE } \\
\text { SSE } \\
\text { SSE } \\
\text { SSE }\end{array}$ & $\begin{array}{r}6 \\
9 \\
36 \\
30\end{array}$ & $\begin{array}{l}0.10 \\
0.09 \\
0.15 \\
0.10\end{array}$ \\
\hline
\end{tabular}

lack of recoveries on Mondays. The expected recovery rate per day is $14 \%$ for any single day of the week and $28 \%$ for weekends. During this study, $34 \%$ of all returns occurred on weekends and only $9.5 \%$ of all

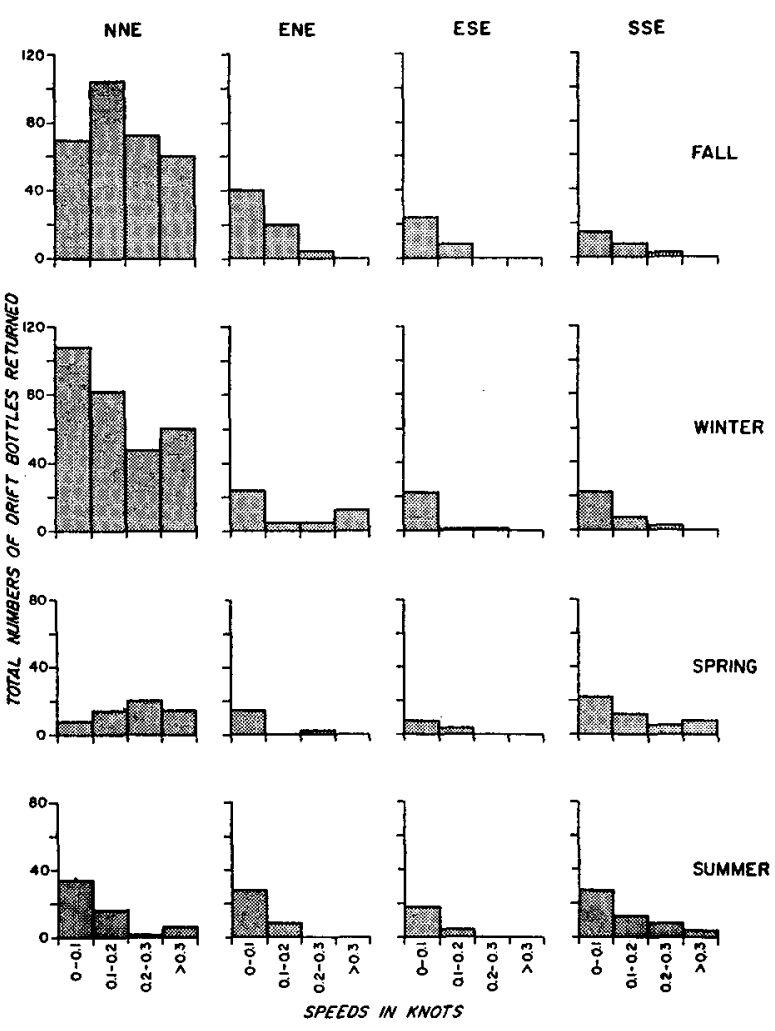

Fig. 1. Histograms of speed pertaining to the four quarters of the year and four different octants of direction off Oregon, 196171. returns occurred on Mondays. Schwartzlose (1964) found $41 \%$ of the drift bottles recovered were found on weekends along the California coast.

Drift bottle returns were also used to estimate speed and direction of surface currents. The results are summarized in Table 3 and Fig. 1. For estimates of speed, a straight line course was assumed between release and recovery. For estimates of time at sea, the duration between release and recovery was used. Using this method, changes in direction of currents are only crudely depicted, and speed, of course, is underestimated.

In the spring and summer, drift bottle returns are low and the validity of some current estimates are questionable. It is during this period that upwelling is prominent and the surface currents associated with upwelling off Oregon are southward with an offshore component near the coast. This type of flow has been well documented by Collins (1968), Mooers (1970), and Hopkins (1971). Duxbury et al. (1966) confirm the presence of a general southerly flow offshore west of Oregon from their work with the distribution of the Columbia River effluent water. For the purposes of this paper, a lack of drift bottle returns during summer is considered an indicator of flow to the south with an offshore component near shore.

\section{Annual cycle of surface currents}

It is generally known that surface currents off Oregon flow equatorward in the summer when winds are from the northwest, and poleward in the winter when winds are from the south (Jones, 1918; Marmer, 1926; Barnes and Paquette, 1954). The general drift patterns of bottles released over the years are summarized in Fig. 2. These patterns are characterized 

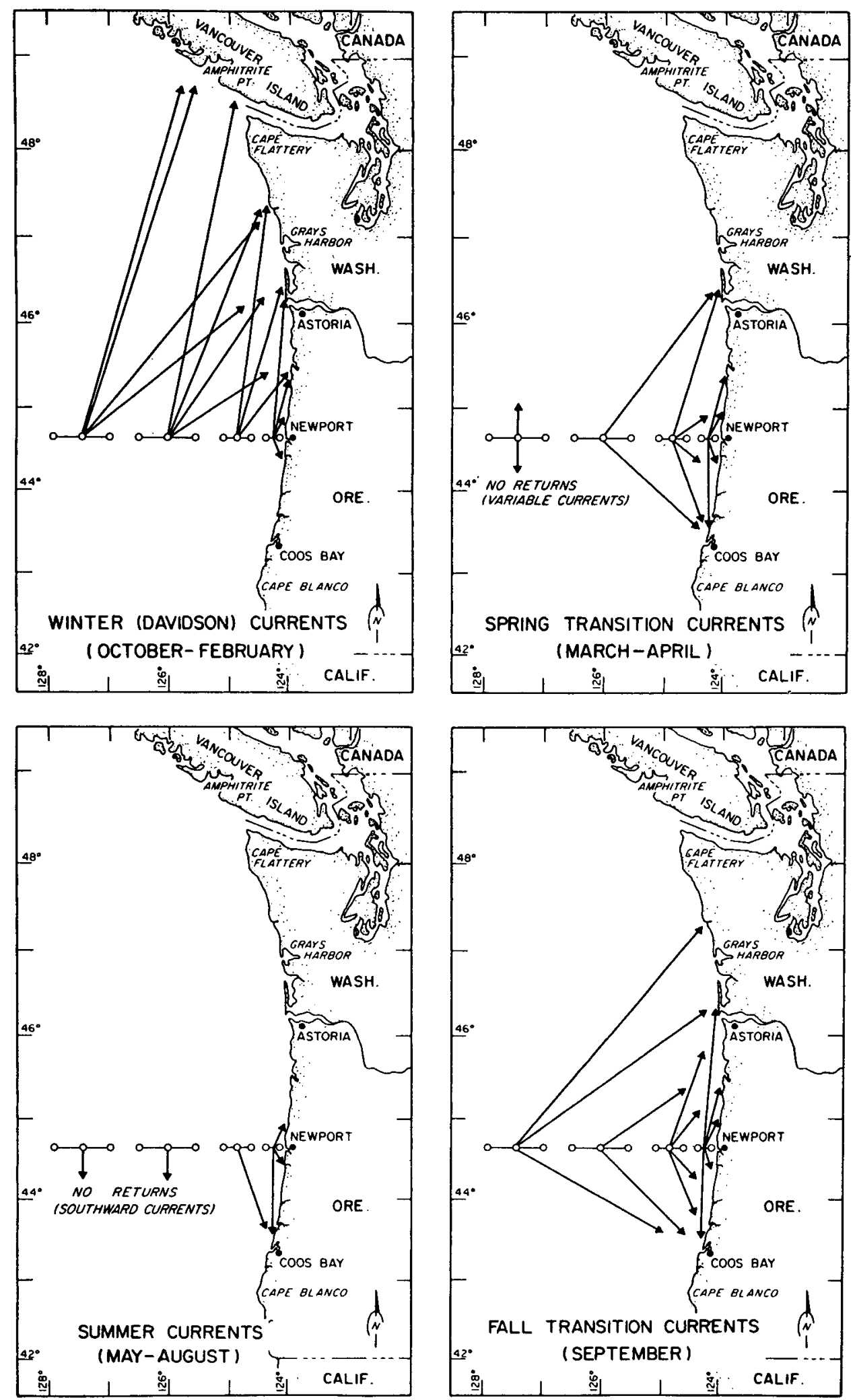

FIG. 2. General patterns of drift bottle returns off Oregon, 1961-71, as they depict seasonal currents. 
below :

\begin{tabular}{|c|c|c|}
\hline Designation & Time & $\begin{array}{l}\text { Direction } \\
\text { of drift }\end{array}$ \\
\hline Winter current (Davidson) & October through February & Northward \\
\hline $\begin{array}{l}\text { Spring transition currents } \\
\text { Summer currents }\end{array}$ & $\begin{array}{l}\text { March and April } \\
\text { May through August }\end{array}$ & $\begin{array}{l}\text { Variable } \\
\text { Southward }\end{array}$ \\
\hline Fall transition currents & September & Variable \\
\hline
\end{tabular}

The Davidson current (winter current) is considered any northward prevalence of surface flow. In this study the strongest prevalence of northward flow occurred in the months of December and January, when over $90 \%$ of all drift bottle returns had trajectories to the north (Table 2). In March and April, a change in direction of flow occurs from northward to southward. May generally marks the beginning of sustained southward-flowing currents which persist through August in most years. Drift bottle returns reach the annual minimum during the summer, with many offshore station releases completely unrecovered (Table 2). In September, currents are variable and the onshore surface component is prominent. Return rates reach their annual high of $30 \%$ for this month (Table 2).

The data on direction of surface drift compare closely with data presented by Panshin (1967) on the magnitude of the annual wind stress $\tau_{y}\left(\mathrm{dyn} \mathrm{cm}^{-2}\right)$ along north and south directions. These wind stress data were derived from geostrophic winds from a station about $30 \mathrm{n} \mathrm{mi}$ west of Newport. Panshin's wind stress data are presented as the two curves in Fig. 3, while a second abscissa scale shows the direction tendency for surface currents derived from our drift bottle studies. In the winter when surface wind stress was directed to the north, surface currents went north-

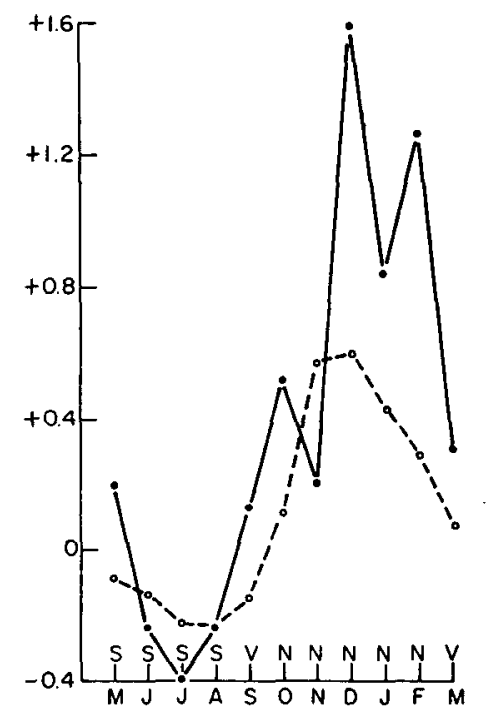

Fig. 3. Comparison of wind stress and surface currents. Monthly means of $\tau_{y}\left(\right.$ dyn $\left.\mathrm{cm}^{-2}\right)$ at $45 \mathrm{~N}, 125 \mathrm{~W}$. The solid line is $\tau_{y}$ for $1933-$ 34 , the dashed line the monthly mean $\tau_{y}$ over a 20 -year period. A positive value of $\tau_{y}$ represents a wind from the south. The monthly means start with May and stop with March. S designates a southward current, $N$ a northward current, and $V$ a variable current, nortlwward and southward: ward. In the summer the opposite case occurred. During the period of transition currents (March), the wind stress on the average was still directed northward, indicating that on the average currents during March might also be northward. The time of the change in direction of the wind stress from southward to northward agreed almost exactly with the onset of currents classified as transitional in September.

\section{Davidson current}

Descriptions of the Davidson current off the North American continent were first recorded in the Cnast Pilot in 1889 (Davidson, 1889). Excerpts from the section on sailing directions from Point Reyes to Cape Flattery include: "The current inshore is an eddy current setting in the opposite direction, parallel with the bends in the coastline. This current is of unknown width and velocity; it is apt to increase in both during periods of light northwest winds, and still more in southerly winds." Northward flow at depth off the California coast was first described by Sverdrup and Fleming (1941) from considerations of water masses. Later, Reid (1962) confirmed the presence of this northward flow at $35 \mathrm{~N}$ with the aid of drogue current measurements at $250 \mathrm{~m}$ depth. Off Oregon, Dodimead et al. (1963) used geostrophic flow calculations, $200 \mathrm{db}$ relative to $1000 \mathrm{db}$, to delineate a northward flowing current which they called the "California Undercurrent." Sverdrup et al. (1942) made this general assessment of the currents off Oregon and California: "In the fall upwelling ceases and in the surface layers a countercurrent develops, the Davidson Current which in November, December and January runs north along the coast to at least $48 \mathrm{~N}$. In this season the subsurface countercurrent still exists and the main difference between the seasons without and with upwelling is therefore that in the former a countercurrent is present at all depths on the coastal side of the California Current, whereas when upwelling takes place the countercurrent has disappeared in the surface layer where instead a number of long stretched surface swirls have developed." The relationship, if it exists, between the deep countercurrent and the Davidson current has still not been established. Burt and Wyatt (1964) and Schwartzlose (1964), using drift bottles, presented evidence for the Davidson current at the surface in fall and winter off Oregon. The present study provides an additional description for this major current found off northern California and Oregon.

The time of occurrence of the Davidson current was monitored over the years from 1961 to 1971. Drift bottle observations were made on 79 of 120 months, and observations were well distributed throughout the months over the years. The Davidson current begins to develop in September and is always apparent from drift bottle returns in October. Drift bottles released on 35. occasions between Octaber and February over 
the 10-year study indicated northward flow on all but five releases. During this time, ten times as many drift bottles traveled north compared to bottles that moved south.

The northward extent of the Davidson current has been stated to be at least $48-50 \mathrm{~N}$ by Burt and Wyatt (1964), Schwartzlose (1964), and Sverdrup et al. (1942). Drift bottle returns were observed regularly between 48 and $50 \mathrm{~N}$. About $30 \%$ of all returns from station releases seaward of $105 \mathrm{mi}$ offshore were recovered in this region.

Every winter of the 10-year study, a few drift bottle returns occurred on the coastal region of British Columbia and southeast Alaska (50-60N), indicating at least some flow of the Davidson current into this region. In October and November of 1964, two sets of nearly simultaneous releases of drift bottles were made by Oregon State University (OSU) off Coos Bay, Newport and Astoria, Ore., and by the Bureau of Commercial Fisheries (Fisk, 1970) off Vancouver Island $(49 \mathrm{~N})$. The majority of returns from OSU releases were picked up off northern Oregon and southern Washington. Seven bottles were picked up between 50 and $60 \mathrm{~N}, 300$ to $900 \mathrm{mi}$ north of release points in the time period between February and June 1965. Bottle returns of Fisk (1970) showed northward movement and were picked up along the coast from 50 to $56 \mathrm{~N}$ at about the same time OSU bottles were found, suggesting spatial continuity of the Davidson current.

Mean speeds for winter surface currents have been computed as $0.2 \mathrm{kt}$, or a drift of $150 \mathrm{mi}$ per month (Table 3). During the period of the Davidson current, water originating off Newport in October might be expected to reach southeast Alaska in late February. Similarly, water off Cape Mendocino (40N) in October might be found off Vancouver Island in February. The highest speeds in the Davidson current over the 10-year study were found within about $20 \mathrm{mi}$ off the coast during November. During the 10 -year study, only 75 returns were recorded with speeds in excess of $0.5 \mathrm{kt}$, only five returns had speeds over $1.0 \mathrm{kt}$, and one return reached a maximum of $2.0 \mathrm{kt}$. Of these, $90 \%$, or 75 returns, were from release points within $15 \mathrm{mi}$ off the coast, and $75 \%$ of these returns came during the month of November. This strong alongshore current near the coast is often apparent from drift bottle releases 3-5 mi offshore from Newport that are recovered $50-150 \mathrm{mi}$ north of Newport. The Davidson current is also visually apparent at times during periods with strong winds from the south as it transports silty river water rapidly northward.

The western extent of the Davidson current is difficult to determine. It may interface or intermingle with either the northward Alaska current or the southward flowing California current, depending on the season and the latitude. Observations of geostrophic flow off Oregon from the surface to $200 \mathrm{~m}$ depth for January ,
1971 indicated flow to the north inside of about $75 \mathrm{mi}$ offshore. Seaward of $75 \mathrm{mi}$ offshore, the flow was to the southward (Wyatt, 1971). Lee (1967) found that over the annual cycle, average geostrophic flow (0 relative to $1000 \mathrm{db}$ ) was northward within $100 \mathrm{n} \mathrm{mi} \mathrm{of} \mathrm{the}$ coast and seaward of this the current was northward. Although drift bottle observations often indicate a northward surface current all the way to at least the edge of the study area, $165 \mathrm{mi}$ offshore, it is believed that the main flow of the Davidson currents occurs within $100 \mathrm{mi}$ of the coast off Washington and Oregon.

The occurrence of winds from the north or northwest apparently causes a decrease in northward surface currents, and it may even result in current reversals. An example of this was observed in the winter of 1964 when northwest winds were unusually persistent. Oregon coastal winters are usually dominated by passage of low pressure cells and associated weather fronts. Occasionally a high pressure ridge with associated winds from the north will persist along the coast for periods of time on the order of a week. In February and March of 1964, high pressure and resulting winds from the north dominated the weather for several weeks. The Oregon coast had the second driest spring ever recorded as a result of this high pressure (American Meteorological Society, 1964). In February and April of 1964, 708 drift bottles were released off Oregon and only four bottles were returned, indicating southward currents and offshore flow. Synoptic weather maps suggest that a period of winds from the north, of shorter duration, probably resulted in the low returns for February 1965 (Table 1).

Cross and Small (1967) suggested that the occurrence of a small copepod, Acartia danae Giesbrecht, might be linked with the northward flowing Davidson current. Even though Acartia danae appeared to be endemic to waters farther than $100 \mathrm{mi}$ offshore, it was only found between the Oregon coast and $65 \mathrm{n} \mathrm{mi}$ offshore between the months of October and May. The time of occurrence of Acartia danae for nearshore waters in October coincides exactly with the onset of the Davidson current in fall. The occurrence of this copepod during the time of spring transition currents in March and April is also reasonable. This inshore occurrence of Acartia danae from October to May is probably a good indicator of shoreward surface drift in winter. Its value as a possible indicator of the Davidson current should be studied in more detail.

\section{Summer surface currents}

Surface currents from May through August are generally southward. Nearly all drift bottle returns were from releases within $35 \mathrm{mi}$ of shore (Table 2). The majority of the returns were found south of release points. Speed estimates in the southward flow were obtained from the few returns that did occur. It is felt that drift bottles released in summer may be sub- 
jected to greater than average offshore currents caused by upwelling or surface divergence described for this area by Smith (1968). The resulting speed estimates from these bottles are undoubtedly too low. The mean speed for returns in summer for bottles traveling southeastward was $0.11 \mathrm{kt}$ (Table 3). A few higher speeds were noted $(\sim 0.30 \mathrm{kt})$, but it is generally felt that the average drift is probably between the mean speed calculated, $0.11 \mathrm{kt}$, and the maximum speed of $0.30 \mathrm{kt}$. A speed of $0.20 \mathrm{kt}$ would be the same figure calculated for winter currents, and it will be used as an estimate of net drift for summer currents. A mean speed of $0.20 \mathrm{kt}$ also compares well with the mean speed of 0.18 $\mathrm{kt}$ calculated for $10 \mathrm{~m}$ drogues off Newport by Stevenson et al. (1969). A net drift of $5 \mathrm{mi} \mathrm{day}^{-1}, 0.20 \mathrm{kt}$, would result in surface water traversing the coast from north to south in about 50 days. Several times during the study, stronger surface currents were indicated. In May 1968, a bottle released $15 \mathrm{mi}$ off Newport was picked up 45 days later near San Francisco. The bottle traveled $450 \mathrm{mi}$ with a minimum speed of about $0.40 \mathrm{kt}$. During this same cruise, bottles released 3, 5 and $15 \mathrm{mi}$ off Newport had southward trajectories of 45 to $175 \mathrm{mi}$ and a median speed of $0.31 \mathrm{kt}$. Speeds near $0.30 \mathrm{kt}$ and movements of over $100 \mathrm{mi}$ southward were also indicated from returns from releases in July 1962 and 1967. One southern return was received from the Hawaiian Islands from a release $20 \mathrm{mi}$ west of Newport on 2 July 1968. The bottle was at sea 325 days and had a minimum speed of $0.28 \mathrm{kt}$ over at least a $2166 \mathrm{n}$ mi course.

During some years in August, winds from the south appear, and drift bottle returns increase above the summer average. A good example of this occurred in August 1962 when a southerly storm passed the coast. During this period, Lane (1965) reported warming of nearshore waters and inshore movement of Albacore tuna Thunnus alalunga. Drift bottle returns from releases off the coast in late July indicated southward flow up until the time of the storm and eastward (onshore) movement at the time or after the storm. Two bottles released within $25 \mathrm{mi}$ of the coast traveled $200 \mathrm{mi}$ southward in 25 days before they came inshore. Returns from releases 35 and $45 \mathrm{mi}$ offshore were fairly numerous but did not travel as far southward as ones released $25 \mathrm{mi}$ from shore. This is a case when onshore surface flow greatly influenced the nearshore coastal waters and the distribution of Albacore tuna.

\section{Currents of transition}

In the spring (March and April), the northward Davidson current is replaced by currents to the south and southwest. The direction change of the currents depends at least in part on the wind, and the transition of currents is not always completed with the onset of the first northwest winds. Burt and Wyatt (1964) reported on currents that shifted from northward to southward at least once during the spring transition period. Observations of current direction were made on 13 occasions in March and April during the 10-year study. On 7 of 13 releases, currents indicated from returns were dominately southward; three times currents were dominately northward; and three times currents were "mixed," or some drift bottle returns were received from both north and south.

In the fall (September), currents shift back to the northward. "Mixed currents" were generally indicated during this period (Table 1). Currents toward shore were especially prominent, as indicated by high returns of drift bottles. The recovery rate at stations 65 and $145 \mathrm{mi}$ offshore was $57 \%$ and $33 \%$, respectively, for the 10-year study. The return rate for all releases off Newport was $30 \%$. Stevenson et al. reported $0.9 \mathrm{kt}$ eastward (onshore flow) currents at $10 \mathrm{~m}$ depth from drogues in September 1962 off Newport. Mean speeds for drift bottle returns in September were $0.08 \mathrm{kt}$.

\section{Recommendations for further research}

More current studies are needed in the area of the Davidson current. Since this current is most well developed during the winter season of high winds, direct measurements have been difficult to obtain. Spot measurements have been made with both current meters (Collins, 1968; Hopkins, 1971) and drogues (Stevenson, et al. 1969) off Newport. Data on continuity, offshore extent, and depth of the Davidson current are noticeably lacking. Simultaneous measurements with parachute drogues, drift bottles, current meters, and a GEK (geomagnetic electro-kinetograph) within $150 \mathrm{n} \mathrm{mi}$ of the coast of Oregon and northern California would greatly enhance our physical description of this current. More work is also needed to detail the biological significance of this northward winter flow. A copepod, Acartia danae, has been linked with the occurrence of the Davidson current. Pacific salmon, Oncorhynchus, migrations may also be influenced by this current.

Acknowledgments. Thousands of persons contributed to the success of this project by returning information on drift bottles they recovered along the Pacific Northwest coast. Hundreds of students helped with the project by releasing drift bottles from research vessels. In particular, Bill Gilbert, Dennis Barstow, James Washburn, Mark Halsey and Lyndal Brixius made this project possible by doing much of the data processing and record keeping.

This work was supported by Office of Naval Research under Contract N00014-67-A-0369-0007, Project NR 083-102.

\section{REFERENCES}

American Meteorological Society, 1964: Weathervise, 17, 59-98. Barnes, C. A., and R. G. Paquette, 1954: Circulation near the 
Washington coast. Tech. Rept. No. 17, Dept. of Oceanography, University of Washington, $31 \mathrm{pp}$.

Burt, W., and B. Wyatt, 1964: Drift bottle observations of the Davidson current off Oregon. Studies on Oceanography, University of Tokyo Press, 156-165.

Collins, Curtis A., 1968: Descriptions of measurements of current velocity and temperature. Ph.D. thesis, Oregon State University, Corvallis, $154 \mathrm{pp}$.

Cross, F. A., and L. F. Small, 1967: Copepod indicators of surface water movements off the Oregon coast. Limnol. Oceanogr., $12,60-72$.

Davidson, George, 1889: Coast Pilot of California, Oregon and Washington. Washington, D. C., Government Printing Office, 308 pp.

Dodimead, A. J., F. Favorite and T. Hirano, 1963: Salmon of the North Pacific Ocean-Part II. Review of oceanography of the subarctic Pacific region. Intern N. Pacific Fish. Comm. Bull., 13, 195 pp.

- , and H. I. Hollister, 1962: Canadian drift bottle releases and recoveries in the North Pacific Ocean. Pacific Oceanographic Group, Ms. Rept. Ser., No. 141, 64 pp.

Duxbury, A. C., Betty-Ann Morse and Noel McGary, 1966: The Columbia River effluent and its distribution at sea, 1961-1963. Tech. Rept. No. 156: Dept. of Oceanography, University of Washington, $105 \mathrm{pp}$.

Fisk, D. M., 1970: Recoveries in 1964-1968 of drift bottles released from a merchant vessel $S S J a v a ~ M a i l$, enroute Seattle to Yokohama, October 1964; Pacific Sci., 25, 171-177.

Hopkins, T. S., 1971: On the circulation over the continental shelf off Washington. Ph.D. thesis, University of Washington, Seattle, $204 \mathrm{pp}$.

Jones, E. L., 1918: The neglected waters of the Pacific Coast. Spec. Publ. U.S. Coast Geodetic Survey, 8, 21 pp.
Lane, R. K., 1965: Wind, nearshore ocean temperature, and the Albacore tuna catch of Oregon. Res. Briefs, Fish Comm. Oreg., 11, 25-28.

Lee, Kuo-heng, 1967: Geopotential anomaly and geostrophic flow off Newport, Oregon. M.S. thesis, Oregon State University, Corvallis, $40 \mathrm{pp}$.

Marmer, H. A., 1926: Coastal currents along the Pacific coast of the United States. Spec. Publ. U.S. Coast Geodetic Survey, $121 \mathrm{pp}$.

Mooers, C. N. K., 1970: The interaction of internal tide with frontal zone. Ph.D. thesis, Oregon State University, Corvallis, $480 \mathrm{pp}$.

Panshin, D. A., 1967: Sea level, winds, and upwelling along the Oregon coast. M.S. thesis, Oregon State University, Corvallis, $71 \mathrm{pp}$.

Reid, J. L., Jr., 1962: Measurements of the California countercurrent at a depth of 250 meters. $J$. Marine Res., 20, 134-137.

Smith, R. L., 1968: Upwelling. Oceanogr. Marine Biol. Ann. Rev., Vol. 6, London, George Allen and Unwin Ltd., 6, 11-46.

Stevenson, M. R., J. G. Pattullo and B. Wyatt, 1969: Subsurface currents off the Oregon coast as measured by parachute drogues. Deep-Sea Res., 16, 449-461.

Sverdrup, H. U., and R. H. Fleming, 1941: The waters off the coast of Southern California, March to July 1937. Bull. Scripps Inst. Oceanogr., 4, 261-378.

_- M. Johnson and R. H. Fleming, 1942: The Oceans. New York, Prentice-Hall, $1087 \mathrm{pp}$.

Schwartzlose, R. A., 1964: Nearshore currents of western United States, Baja, California, as measured by drift bottles. CALCOFI Progress Rept. 1, July 1960-June 1962, California Dept. of Fish and Game, Sacramento, 15-22.

Wyatt, Bruce, 1971: Unpublished hydrographic data. Oregon State University, Corvallis. 